\title{
Indonesia's Energy Relations with the Gulf Cooperation Council Countries: Drivers and Progress
}

\author{
Zulfikar Rakhmat $^{1, *}$, M. Habib Pashya ${ }^{1}$ \\ ${ }^{1}$ Department of International Relations, Faculty of Psychology and Socio-Cultural Sciences, Universitas Islam Indonesia. Jl. \\ Kaliurang No.Km. 14,5, Krawitan, Umbulmartani, Kec. Ngemplak, Kabupaten Sleman, Daerah Istimewa Yogyakarta 55584, \\ Indonesia \\ *Corresponding Author: muhzulfikar@uii.ac.id
}

\author{
Article History \\ Received 2 August 2021 \\ Accepted 2 February 2022 \\ Available 27 February 2022
}

\begin{abstract}
Located on opposite ends of Asia, Indonesia and the Gulf Cooperation Council (GCC) member states have developed dense and multifaceted relations in recent years. Trade and economic relations have been foundational in developing these ties, with energy playing an important role. Energy has long been at the heart of Indonesia-GCC trade. The relations have expanded from traditional energy such as oil and gas to renewable energy. This article examines the progress of IndonesiaGCC relations, particularly in the energy field. It looks at the major past and present developments in the energy cooperation between Indonesia and the Gulf countries, including exports, imports, as well as investments. In doing so, the paper also examines the drivers behind the growing cooperation.
\end{abstract}

Keywords:

Indonesia, the Gulf, Energy, the GCC, the Gulf Cooperation Council

\section{Introduction}

The relationship between Indonesia and the Gulf Cooperation Council (GCC) countries-Saudi Arabia, Qatar, Kuwait, the UAE, Bahrain and Oman-has expanded in many sectors from political, economic and socio-cultural cooperation. On the economic front, trade between Indonesia and the GCC countries has risen by 40\%, from USD 8.68 billion in 2016 to USD 12.15 billion in 2018 (Tempo, 2019). At the same time, investments also rose by 26\%, from USD 60.3 million in 2016 to USD 76.1 million in 2018 (Kementerian Luar Negeri Republik Indonesia, 2019). In addition, an economic partnership framework arrangement has also been established, which includes a free trade agreement (FTA), between the government in Jakarta and the six GCC countries. The agreement offers a gateway for Indonesia to strengthen ties with all countries of the GCC. Indonesia's trade with Bahrain in 2018, for example, stood at USD 116 million, with an export value of USD 46.67 million (Rakhmat et al., 2021). Meanwhile, between January and September 2019 Indonesia-Kuwait trade reached USD 389.68 million (Rakhmat et al., 2021). The cooperation, however, has not only focused on economic affairs, but also in political, as well as socio-cultural spheres.

Energy has been the focus of Indonesia-GCC relations. Although Western nations had been the major market for energy resources from the Gulf, Asian states have increasingly become some of the biggest importers of the GCC countries' natural gas and oil. Of all countries in Asia, Indonesia has increasingly become a major energy partner of the GCC states. While Indonesia has its own energy sources, they are increasingly depleted and therefore unable to fill its growing needs. At the same time, with potential economic downturn in the West and China caused by trade war and the COVID-19 pandemic, the UAE has attempted to find alternative partners and Indonesia has been one of them (LaRocco, 2019). As a result, the energy cooperation between Indonesia and the Gulf countries has been expanding in recent 
years, not only in terms of energy trade, but also energy investments. Studies on Indonesia-Middle East relations are limited (Rakhmat et al., 2021), let alone on the energy ties between Indonesia and GCC relations. The available literatures related to the relations between Indonesia and the Middle East have been primarily focused on culture and the roles of Islam (Al Qurtuby, 2019; Azra, 2004; Bubalo \& Fealy, 2005; Eliraz, 2004; Hadiz, 2015).

This paper thus aims to examine the progress of Indonesia-GCC relations, particularly in the energy field. It looks at the major past and present developments in the energy cooperation between Indonesia and the Gulf countries, including exports, imports, as well as investments. In doing so, the paper also examines the drivers behind the growing cooperation. By being the paper that specifically focuses on the energy aspect of Indonesia-GCC ties, this paper presents a major contribution to the existing literatures on Indonesia-Middle East relations.

\section{Research Method}

This paper adopts a case study approach, which emphasises the concept of 'focus'. This approach can be identified as a qualitative approach which investigates "a bounded system (a case)" over a certain period by way of thorough data collection from various sources (Cresswell, 2007). The emphasis on "focus" in this approach signifies taking "a particular case and com[ing] to know it well, not primarily as to how it is different from others but what it is, what it does" (Stake, 1995). This approach has been adopted in the field of international relations as it allows the holistic understanding of global phenomena (Yin, 2009). The case study that is the focus of this research is the drivers and progress of IndonesiaGCC energy relations.

In regards to data analysis, the researchers describe the case and its setting in detail. 'Direct interpretation' is employed as it is the kind of data analysis and interpretation that the case study approach proposes. As Cresswell (2007) points out, 'direct interpretation' enables the attainment of meaning from a specific event. It is further elaborated that 'direct interpretation' can be done by "pulling the data apart and putting them back together in a more meaningful way" (Cresswell, 2007).

This research primarily relies on published and unpublished secondary works in English in the form of books, journals, book chapters and policy briefs. These sources are substantiated with non-peerreviewed resources, primarily media articles from well-known publications. The contemporary character of the energy relations between Indonesia and GCC countries signifies that many of the developments have only recently taken place; as such, media articles are important resources for this paper. They provide the latest information on the relationship. For reliability, nevertheless, the information in these journalistic sources is not taken for granted. Besides only gaining information from well-respected publications, cross-checking the information obtained is carried out, either by comparing them with other sources. Finally, statistical documents from numerous institutions to gain data to support the paper's analysis are also used.

\section{Results and Discussion}

Indonesia's energy cooperation with the GCC countries comes from different factors. The most important driver is the GCC's position in the global energy industry. The GCC contains $29.4 \%$ of the total oil reserves in the world and about $25 \%$ of the total natural gas reserves (BP, 2014). According to a report by Statistical Review of World Energy (2021), fossil fuel produced by the GCC countries reached 695.8 million/1297.3 per barrel. This production is far from that of Central and South America, which is only 300.3 per barrel. This high oil production capability is also combined with its natural gas production. In 2020, the Gulf produced 407.1 billion cubic meters of natural gas, which was among the largest in the world (BP, 2021).

At the same time, Indonesia is in need of large amounts of energy to meet its economic development. Its total energy needs primarily come from petroleum or fuel oil $(54.04 \%)$ and natural gas $(21.94 \%)$ 
(Siregar \& Zulkarnain, 2021). Indonesia presently imports crude of 400,000 barrels/day, with the majority of imports from the Middle East (Gueraiche \& Alexander, 2022). Based on a report by the U.S. Energy Information Administration in 2020, Indonesia's crude oil imports mostly originated from Saudi Arabia, followed by other countries such as Malaysia (U.S. Energy Information Administration, 2021).

Indonesia's energy relations, especially in the oil sector, with the Gulf countries are mostly dominated by its ties with Saudi Arabia and Kuwait. This is possibly due to the two countries' position in the global oil market. Saudi Arabia owns 15\% of the world's oil reserves, making it the largest holder among OPEC member countries. The U.S. Energy Information Administration reported that the Kingdom has the ability to produce 12 million barrels daily (the U.S. Energy Information Administration, 2021). Meanwhile, Kuwait has the $5^{\text {th }}$ world's largest oil reserves of 101.5 billion barrels (Stebbins, 2019).

With regards to Saudi Arabia, it has been the largest exporter of fossil fuels to Indonesia. In 2019, about 48 percent of Indonesia's crude oil import was supplied from Saudi Arabia (Indonesia Window, 2020). As for Kuwait, Indonesia's total import of oil and gas reached USD 214 million (Ministry of Foreign Affairs of The Republic of Indonesia, 2019). Besides energy trade, investments also constitute an important component of Indonesia's energy cooperation with Kuwait and Saudi Arabia. The primary factor behind this is that Indonesia is still in need of energy infrastructure development in its underdeveloped regions, such as in the Eastern part of the country (World Bank, n.d.). In addition, Indonesia views that energy investments from the Gulf countries would contribute to the efforts to meet its growing energy consumption capacity (Hartono et al., 2020). With Kuwait, the most crucial investment took place in 2010 when the Kuwait Foreign Petroleum Exploration Company (KUFPEC) purchased shares in the Indonesian unit of ConocoPhillips, which owns a $25 \%$ stake in the Ujung Pangkah block in the East Java Sea (Rakhmat et al., 2021). It is also reported that the company has invested USD 45 million in Non-Block Bula on Seram island and in Block A gas field in West Natuna (Rakhmat et al., 2021). With high interests in Indonesia's growing energy market, another Kuwaiti energy company, Kuwait Petroleum International Ltd. has also signed a partnership with South Korea's SK Energy Co. in 2012 to cooperatively build a 30,000 barrels per day (bpd) refinery in Indonesia. Although this is not the largest refinery to be built in Indonesia, it represented an opening for the Gulf countries to invest in Indonesia. This was evidenced by the fact that the deal was followed by another agreement signed between Pertamina and Kuwait Petroleum Company (KPC) to invest USD 9 billion in a refinery joint venture in Balongan, West Java, with expected output of 300,000 bpd (Rakhmat et al., 2021). In 2013, the KPC also planned to develop a USD 7 billion refinery in Indonesia, even though it was later canceled (Asian Development Bank, 2016). The cancellation was caused by the Indonesian government's inability to fulfill several requests from the KPC concerning fiscal incentives, a tax holiday for 30 years, as well as a $5 \%$ tax on import reductions and local taxes.

Although Saudi Arabia is the largest exporter of energy resources to Indonesia, it has the most unpopular story when it comes to GCC's energy investments in Indonesia. For Indonesia, investments from Saudi Arabia could serve as an opportunity to fund its energy goals (Kai-ren, 2017). Negotiations were pursued by Pertamina and Saudi Aramco on a USD 6 billion refinery joint venture in Cilacap, Central Java (Wang, 2016). In the midst of the discussions, however, Saudi Aramco walked away, which had dragged the deal for nearly five years. Reportedly, the primary factor behind the bickering was that Aramco perceived the valuation of the project to be very high. Although the Saudi giant had increased the valuation from USD 2.5 billion to USD 5.1 billion (The Wall Street Journal, 2021), Pertamina believed that the required funds to develop the refinery would be at least USD 5.7 billion (Energy Voice, 2020). There were, nonetheless, reports stating that Aramco's refusal was caused by other reasons. The firm's CEO, Amin H. Nasser, was reportedly having uneasy relations with individuals in Pertamina's leadership, especially its director Nicke Widyawati (Energy Voice, 2020). The Saudi Arabian company felt that it had been used by Nicke to secure her position through making it seem that Aramco would invest in the Cilacap refinery project. To date, Pertamina is still looking for Aramco's replacement (Energy Voice, 2020). Nonetheless, this story does not stop Indonesia and Saudi Arabia from continuing their energy partnership. In mid-2020, Coordinating Minister for Maritime Affairs and Investment 
Luhut Pandjaitan went to Riyadh to meet with Saudi Arabia's investment and finance ministers. Among all of the points discussed was energy investments, although details have not been released yet to public (Musyaffa, 2020).

In addition to Saudi Arabia and Kuwait, Indonesia has also garnered energy relations with the UAE. Even though the UAE was not a close partner of Indonesia, Jakarta-Abu Dhabi relations have grown significantly during Jokowi's era. The recent strengthening of Indonesia-UAE ties was demonstrated when Jokowi visited Abu Dhabi in mid-January 2020 and signed 16 agreements with the UAE's Crown Prince Mohammed bin Zayed (Monitor, 2020). Energy agreements have also been signed between the two countries recently. The most crucial is a USD 270 million deal on liquefied petroleum gas between Indonesia's state-owned energy corporation PT Pertamina and the Abu Dhabi National Oil Company (ADNOC) (Setiawan, 2020), which can be considered as the largest energy deal between the two countries. The two companies, along with the UAE's investment vehicle, Mubadala, also signed a memorandum of understanding (MoU) titled, "Evaluat[ing] a Potential Crude to Petrochemical Complex Project at Balongan" in West Java worth USD 12.6 billion (Rakhmat et al., 2021). Those agreements were also accompanied by another USD 3 billion long-term deal on naphtha supply between ADNOC and PT Chandra Asri Petrochemical Tbk (Rakhmat et al., 2021). The Indonesia-UAE energy ties, however, are not one-way. Even though details are not available yet, Pertamina has been reportedly in negotiations to procure a gas and oil block in the UAE as part of the efforts to increase Indonesia's gas and oil production (Nugraha \& Rakhmat, 2020). UAE's interests in Indonesia's energy sector could be caused by the declining energy demands among the traditional consumers of the UAE such as the US and China, whose economies have been affected by the COVID-19 pandemic (Al-Marri, 2017).

Although Indonesia's energy ties with the UAE are relatively modest compared to Saudi Arabia and Kuwait, the UAE is Indonesia's GCC most apparent partner in the renewable energy sector. It is crucial to note that, according to the International Renewable Energy Agency reported that between 2014 and 2018, the Gulf countries had a noticeable expansion of renewable power plant capacity, from $210 \mathrm{MW}$ to 867 MW (International Renewable Energy Agency, 2019). The UAE has almost 69\% of total GCC's renewable power plant capacity (International Renewable Energy Agency, 2019), while Saudi Arabia is ranked second with $89 \mathrm{MW}$. Moreover, the Gulf region also aims to become a leading expert in renewable energy through the construction of the world's largest solar power plant, with a capacity of 1,177 MW (Hawson, 2020). In 2017, the UAE inaugurated its 'Energy Strategy 2050', which is regarded as the country's first unified energy strategy. The objectives are to augment the portion of clean energy in the total energy mix from $25 \%$ to $50 \%$ by 2050 and minimize carbon emissions by $70 \%$ (Masdar Institute, 2015). To accomplish these objectives, the UAE has partnered with Mubadala Investment Company, the Abu Dhabi National Energy Company, and ADNOC which will collaborate with the Abu Dhabi Future Energy Company, Masdar (Mubadala, 2021).

The GCC's greening agenda is inline with Indonesia's renewable energy agenda, which has been a priority of the Joko "Jokowi" Widodo administration with an ambitious target of 23 percent renewables by 2025 (Langer et al., 2021). As of now, however, the country only reached around 9 percent. As a result, the Indonesian government has tried to enact more investment-friendly pricing schemes and regulations to attain its goal (Langer et al., 2021). In order to set a legal certainty for investors, a renewable energy bill has also been included in the national legislation program. Indonesia has also deepened cooperation with the International Energy Agency (IEA) to foster the development of renewable energy in the country (International Energy Agency, 2020). These developments have made Indonesia and its major energy partners such as the Gulf countries to explore renewable energy as a new focus of their cooperation.

Masdar, one of the UAE's prominent companies on renewable energy, has signed a deal with Pembangkitan Jawa Bali, the subsidiary of Indonesia's state electricity company, Perusahaan Listrik Negara (PLN), in constructing the first floating solar power plant in Indonesia. Moreover, the UAE have also poured investments in Indonesia's largest solar power project with a capacity of $145 \mathrm{MW}$, which is projected to operate by 2022 (OECD, 2021). The plant, which is situated in West Java, is aimed 
to provide clean energy across Java Island which has the highest electricity use in the country. Even though Indonesia has also partnered with other countries on renewable energy such as with the US and Denmark, the UAE's inroads into the renewable energy sector in the country would contribute to Jakarta's renewable energy goals. This has also inspired other GCC countries to enter Indonesia's renewable energy sector. Kuwait, for instance, has inked a MoU on renewable energy, although concrete implementation of the MoU has not yet appeared (Kuwait Institute for Scientific Research, 2019).

Beyond the three major GCC countries, Indonesia has also strengthened energy cooperation with smaller regional countries. Indonesia's growing demand for energy resources are raising the profile and significance of all energy exporters, including moderate producers such as Qatar and Oman (BP, 2021). In 2019, exports from Qatar to Indonesia were recorded at USD 947 million, with oil and gas as the main items (Rakhmat et al., 2021). Beyond energy exports, investments have also been gradually pursued. Qatar has also invested in the biggest coal power plant in Paiton. An agreement was also inked in 2017 between the Qatari government and PLN in the development of $800 \mathrm{GW}$, alongside regasification unit and floating storage in North Sumatra (Nugraha \& Rakhmat, 2020). This, nonetheless, is not a one-way exchange. Indonesian investments have also made their way to Qatar.

Pertamina, for instance, has been expanding itself into the Qatar Sector-3 oil and gas block along with European and Japanese firms. Furthermore, Indonesia's relationship with Oman has been centered on energy trade. Although the precise date on energy trade between Indonesia and Oman is not widely available, in the past several years, several agreements on exploration and production have been signed by the two countries. PT Medco Energi Internasional has been operating its wholly-owned subsidiary Medco Oman LLC, which owns a 55\% interest in Karim Small Fields (Rakhmat et al., 2021). As Indonesia's dependence on energy resources from the Gulf is projected to grow in the near future, some efforts have been made by Indonesian energy companies to increase their operations in Oman. Last year, for instance, Medco was working to purchase assets in Oman, while Pertamina was in discussions with Oman to buy assets in its oil and gas industry. Indonesia has declared that it is willing to partner with Qatari firms on oil and LNG explorations (Oil and Gas Middle East, 2015). As a matter of fact, it has invited RasGas and Qatar Petroleum to explore and develop potential oil fields under a production contract sharing scheme (Oil and Gas Middle East, 2015). PT Medco Power Generation Indonesia also made a similar proposal during the "CEO Plenary Session"at the $9^{\text {th }}$ International Petroleum Technology Conference (IPTC) in Doha to explore hard-to-reach regions in eastern Indonesia, which requires considerable investments and technology (Oil and Gas Middle East, 2015).

Bahrain is the only GCC country that has no energy cooperation with Indonesia. Commenced in 1976, Indonesia-Bahrain ties have grown slowly since. The two countries, however, have exerted efforts to upgrade their relations to another level. As an example, the then Indonesian President Abdurrahman Wahid made a diplomatic visit to Manama to discuss ways to improve cooperation. Generally speaking, the Jakarta-Manama partnership has been primarily taking place in the economic sector. In 2016, the trade volumes stood at USD 101.4 million, a considerable jump from USD 76.1 million the previous year. Another considerable growth was further witnessed in 2017, when the total trade more than doubled to USD 206.3 million (Kementerian Luar Negeri Republik Indonesia, 2019). The two countries' trade mainly focuses on iron ore and manufactured vehicles (Trade Map, n.d.). The absence of energy in Indonesia-Bahrain ties may be due to its small size and its status as the smallest gas and oil producer in the Gulf. A report by BP states that Bahrain's oil refining capacity only stood at 260, which can be considered small compared to, for instance, Kuwait, which has 301 capacity (BP, 2021).

\section{Conclusion}

The main objective of this paper is to examine the drivers and progress of Indonesia-GCC relations in the field of energy. It has been demonstrated that the energy cooperation between Indonesia and the countries of the Gulf has been growing not only in terms of trade but also investments. Moreover, these ties have not only taken place in traditional energy resources such as oil and gas. Rather, they have also 
expanded into renewable energy as well. With regards to the drivers of the relationship, these can be divided into two perspectives. From the Gulf's point of view, Indonesia is gradually becoming an important market for their energy exports and investments. With any potential economic downturn in China as well as the US and Europe caused by Beijing's trade war with Washington and now the COVID-19 pandemic, the GCC have tried to find markets elsewhere for their energy resources. From the Indonesian perspective, its increasing energy needs are raising the profile and significance of the GCC countries. Indonesia has a hard time producing 1 million barrels/month (Amir, 2019). Indonesia, the founding member of OPEC, left the organization in 2009 and is now importing larger quantities of oil (Faisol et al., 2020). The country is also in need of foreign investments to revamp its declining energy sector. As the energy relations between Indonesia and the Gulf countries can be expected to grow in the near future, further studies are needed to analyze the continuity of the cooperation.

\section{References}

Al-Marri, F. H. M. A. (2017). The impact of the oil crisis on security and foreign policy in GCC countries: Case studies of Qatar, KSA and UAE. Arab Center for Research \& Policy Studies

Al Qurtuby, S. (2019). Saudi Arabia and Indonesian networks: Migration, education, and Islam. I.B. Tauris.

Amir, H. (2019). Indonesia's effort to phase out and rationalise its fossil-fuel subsidies. OECD. https://www.oecd.org/fossil-fuels/publicationsandfurtherreading/Indonesia\%20G20\%20SelfReport\%20IFFS.pdf

Asian Development Bank. (2016). Indonesia: Energy sector assessment, strategy, and road map. Asian Development Bank.

Azra, A. (2004). Origins of Islamic reform. University of Hawaii Press.

BP. (2021). BP statistical review of world energy. BP. http://large.stanford.edu/courses/2014/ph240/milic1/docs/bpreview.pdf

Bryman, Burgess, A. B. (1994). Analyzing qualitative data. CRC Press.

Bubalo, G., \& Fealy. (2005). Joining the caravan?: The middle east, Islamism and Indonesia. New Society Publisher.

CNN Indonesia. (2015). Pertamina gandeng perusahaan Kuwait garap proyek energi baru. CNN Indonesia. https://www.cnnindonesia.com/ekonomi/20150831201959-85-75726/pertaminagandeng-perusahaan-kuwait-garap-proyek-energi-baru

CNN Indonesia. (2020). Indonesia-Uni Emirat Arab tandatangani 16 kesepakatan. https://www.cnnindonesia.com/ekonomi/20200113042033-92-464703/indonesia-uni-emiratarab-tandatangani-16-kesepakatan

Eliraz, G. (2004). Islam in Indonesia. modernism, radicalism, and the Middle East dimension. Journal of Islamic Studies, 17(3).

Energy Voice. (2020). Politics muddy Indonesia's $\$ 48$ billion refinery expansion plan after Aramco walks. https://www.energyvoice.com/oilandgas/asia/252182/politics-muddy-indonesias-48billion-refinery-expansion-plan-after-aramco-walks/

Faisol, W., Indriastuti, S., \& Trihartono, A. (2020). Indonesia and OPEC: why Indonesia maintains its distance?

Hadiz, V. R. (2015). Islamic populism in Indonesia and the Middle East. Cambridge University Press.

Hartono, D., Hastuti, S., Halimatussadiah, A., Mita, A., Saraswati, A., \& Indriani, V. (2020). Comparing the impacts of fossil and renewable energy investments in Indonesia: A simple general equilibrium analysis. Heliyon, 6(6).

Hawson, P. (2020). The business year: Abu Dhabi 2020. The Business Year.

Indonesia Window. (2020). RI's ambassador, Saudi energy minister discuss energy cooperation. https://indonesiawindow.com/en/ris-ambassador-saudi-energy-minister-discuss-energycooperation/

International Energy Agency. (2020, July 7). Indonesia and IEA deepen cooperation on electricity and renewables to advance energy transitions - News - IEA. International Energy Agency. https://www.iea.org/news/indonesia-and-iea-deepen-cooperation-on-electricity-andrenewables-to-advance-energy-transitions 
International Renewable Energy Agency. (2019). Renewable Energy Market Analysis: GCC 2019. International Renewable Energy Agency. https://www.irena.org/publications/2019/Jan/Renewable-Energy-Market-Analysis-GCC-2019

Jakarta Post. (2010). Qatar wants to invest more in rising Indonesia: Envoy. Jakarta Post. https://www.thejakartapost.com/news/2010/12/21/qatar-wants-invest-more-rising-indonesiaenvoy.html

Jakarta Post. (2013). Kuwait keen to build \$7 billion oil refinery in RI to boost ties. Jakarta Post. https://www.thejakartapost.com/news/2013/02/27/kuwait-keen-build-7-billion-oil-refinery-riboost-ties.html

Jakarta Post. (2013). Pertamina in talks with Oman on ventures. Jakarta Post. https://www.thejakartapost.com/news/2013/05/17/pertamina-talks-with-oman-ventures.html

Jakarta Post. (2020). UAE's Masdar to support development of Indonesia's largest solar power plant. Jakarta Post. https://www.thejakartapost.com/news/2020/01/08/uaes-masdar-to-supportdevelopment-of-indonesias-largest-solar-power-plant.html

Kai-ren, N. (2017). Saudi Arabia's footprints in Southeast Asia. https://thediplomat.com/2017/10/saudi-arabias-footprints-in-southeast-asia/

Kementerian Luar Negeri Republik Indonesia. (2019). Indonesia-Bahrain Sepakat Tingkatkan Kerjasama Ekonomi. Kementerian Luar Negeri Republik Indonesia. https://kemlu.go.id/portal/id/read/574/berita/indonesia-bahrain-sepakat-tingkatkan-kerjasamaekonomi

Kementerian Luar Negeri Republik Indonesia. (2019). Indonesia Perkuat Kerja Sama Ekonomi dengan Negara Teluk. Kementerian Luar Negeri Republik Indonesia. https://kemlu.go.id/portal/id/read/550/berita/indonesia-perkuat-kerja-sama-ekonomi-dengannegara-teluk

Kuwait Institute for Scientific Research. (2019). Kuwait Energy Outlook.

Kuwait New Agency. (2014). Kuwait, Indonesia Trade Volume Reaches USD $130 \mathrm{mln}$. https://www.kuna.net.kw/ArticleDetails.aspx?id=2365559\&language=en\#

Langer, J., Quist, J., \& Blok, K. (2021). Review of renewable energy potentials in Indonesia and their contribution to a 100\% renewable electricity system. Energies, 14(21).

LaRocco, L. A. (2019). Trade war: Containers don't lie, navigating the bluster. Marine Money, Inc.

Masdar Institute. (2015). REmap 2030, renewable energy prospects: United Arab Emirates. IRENA. https://www.irena.org/Imedia/Files/IRENA/Agency/Publication/2015/IRENA_REmap_UAE_report_2015.pdf

Ministry of Foreign Affairs of The Republic of Indonesia. (2019). FM Marsudi inaugurates the first oil and gas corner at Indonesian Embassy in Kuwait: Latest innovation to attract investment in oil and gas sector. Ministry of Foreign Affairs of The Republic of Indonesia. https://kemlu.go.id/portal/en/read/561/view/fm-marsudi-inaugurates-the-first-oil-and-gascorner-at-indonesian-embassy-in-kuwait-latest-innovation-to-attract-investment-in-oil-andgas-sector

Monitor. (2020). Jokowi: UEA akan jadi mitra penting Indonesia di sektor investasi. Monitor. https://monitor.co.id/2020/01/13/jokowi-uea-akan-jadi-mitra-penting-indonesia-di-sektorinvestasi/

Mubadala. (2021, January 17). Mubadala, ADNOC and ADQ form alliance to accelerate Abu Dhabi Hydrogen leadership. Mubadala. https://www.mubadala.com/en/news/mubadala-adnoc-andadq-form-alliance-accelerate-abu-dhabi-hydrogen-leadership

Musyaffa, I. (2020). Indonesia keen to boost investment ties with UAE, Saudi Arabia. Asia-Pasifik. https://www.aa.com.tr/en/asia-pacific/indonesia-keen-to-boost-investment-ties-with-uaesaudi-arabia/2073135

Nugraha, D. B., \& Rakhmat, M. Z. (2020). The greening of Indonesia-Gulf relations. The Diplomat. https://thediplomat.com/2020/07/the-greening-of-indonesia-gulf-relations/

OECD. (2021). Green finance and investment clean energy finance and investment policy review of Indonesia. OECD Publishing. 
Oil and Gas Middle East. (2015). Indonesia eyes Qatar for oil and gas exploration. https://www.oilandgasmiddleeast.com/article-14951-indonesia-eyes-qatar-for-oil-and-gasexploration

Pillai, S. S. (2019, June 29). World's largest solar project, with power enough for 90000 people, switched on in Abu Dhabi. Gulf News. https://gulfnews.com/uae/worlds-largest-solar-projectwith-power-enough-for-90000-people-switched-on-in-abu-dhabi-1.1561799168033

Rakhmat, D. Z., Tingai, F., Pashya, M. H., Purnama, Y., \& Septianie, N. (2021). Ekonomi politik hubungan Indonesia dan negara-negara Arab GCC. Pustaka Pelajar.

Rakhmat, M. Z., Pashya, M. H., Septiani, A., \& Tingai, F. (2021). Indonesia-Oman relationship: Gradually growing with many opportunities. Jurnal Asia Pacific Studies, 5(1).

Gueraiche, W. \& Alexander, K. (2022). Facets of security in the United Arab Emirates. Routledge.

Setiawan. (2020). Gandeng Adnoc, Pertamina siap kembangkan kilang petrokimia Balongan. https://katadata.co.id/ekarina/berita/5e9a4990bdfb4/gandeng-adnoc-pertamina-siapkembangkan-kilang-petrokimia-balongan

Siregar, R., \& Zulkarnain. (2021). Environmentally friendly alternative energy development policies in overcoming the energy crisis. British Journal and Environment Studies, 1(1).

Stebbins, S. (2019, May 22). The largest oil reserves in the world are found in these 15 countries. USA Today. https://www.usatoday.com/story/money/2019/05/22/largest-oil-reserves-in-world-15countries-that-control-the-worlds-oil/39497945/

Suara Investor. (n.d). DPR siap tingkatkan kerjasama dengan Bahrain. Suara Investor. https://www.suarainvestor.com/dpr-siap-tingkatkan-kerjasama-dengan-bahrain/

Tempo. (2019). Kerja sama dagang Indonesia dengan negara teluk naik 40 persen. Tempo https://dunia.tempo.co/read/1241141/kerja-sama-dagang-indonesia-dengan-negara-teluk-naik40-persen

The Wall Street Journal. (2021). Saudi-owned Motiva suspends $\$ 6.6$ billion petrochemical expansion. The Wall Street Journal. https://www.wsj.com/articles/saudi-owned-motiva-suspends-6-6billion-petrochemical-expansion-11626698498

Trade Map. (n.d.). Bilateral trade between Indonesia and Qatar in 2020. n.d

U.S. Energy Information Administration. (2021, September 24). International - US energy information Administration. EIA. https://www.eia.gov/international/analysis/country/IDN

U.S. Energy Information Administration. (2021, December 2). Country analysis executive summary: Saudi Arabia. EIA. https://www.eia.gov/international/analysis/country/SAU

Wang, H. K. H. (2016). Energy markets in emerging economies: Strategies for growth. Taylor \& Francis.

World Bank. (n.d.). Indonesia overview: Development news, research, data. World Bank. https://www.worldbank.org/en/country/indonesia/overview\#1 